Original Paper

\title{
Sosialisasi Penangulangan Sampah Melalui Pendekatan Zero Waste di Kawasan Wisata Savana Propok Lombok Timur
}

\author{
I Gde Mertha ${ }^{1 *}$, Handre Rizkiawan ${ }^{2}$, Ari Satriadi ${ }^{3}$, Pandu Susilo Waskito ${ }^{4}$ \\ ${ }^{1}$ Pendidikan Biologi, FKIP UniversitasMataram, Indonesia. \\ 2 Pendidikan Guru Sekolah Dasar, FKIP Universitas Mataram, Indonesia. \\ ${ }^{3}$ Teknik Elektro, Fakultas Teknik Universitas Mataram, Indonesia. \\ 4 Teknik Informatika, Fakultas Teknik Universitas Mataram, Indonesia.
}

DOI: $\underline{10.29303 / \text { jpmpi.v3i1.449 }}$

Sitasi: Mertha, I.G., Rizkiawan, H., Satriadi, A., Waskito, P.S. (2020). Sosialisasi Penangulangan Sampah Melalui Pendekatan Zero Waste di Kawasan Wisata Savana Propok Lombok Timur. Jurnal Pengabdian Magister Pendidikan IPA, 3(1). doi: https:// doi.org/10.29303/jpmpi.v3i1.449

*Corresponding Author:

I Gde Mertha; Pendidikan Biologi, FKIP

UniversitasMataram, Indonesia.

Email:

igdemertha@yahoo.co.id
Abstrak: Savana Propok merupakan salah satu destinasi wisata yang berada pada area pegunungan di kawasan Rinjani yang dikelola sebagai objek wisata oleh masyarakat sekitar yang tergabung dalam Kelompok Sadar Wisata (Pokdarwis). Untuk menjaga wisata tersebut tetap terjaga kelestarian alamnya dari pencemaran akibat sampah yang dibawa wisatawan, maka perlu diadakan sosialisasi zero waste. Tujuan sosialisasi yaitu untuk memberikan kesadaran dan pemahaman akan pentingnya menjaga kebersihan kawasan wisata baik di area hutan, jalur pendakian,maupun di area Savana Propok tempat camping. Metode yang digunakan untuk sosialisasi zero waste kepada wisatawan yaitu dengan direct selling dan face to face. Setiap kelompok wisatawan diberikan penjelasan pada saat mendaki agar tidak membawa makanan dan minuman yang berpotensi menjadi sampah dan membawa turun sampah bawaannya. Untuk memastikan program zero waste ini berjalan, pada hari-hari berikutnya dilakukan pemantauan dan pendataan dengan memeriksa barang bawaan dari beberapa kelompok wisataran yang telah diberikan sosialisasi untuk memastikan materi yang telah disosialisasikan dapat diterima atau diterapkan oleh wisatawan yang akan kembali ke Savana Propok. Berdasarkan hasil pengamatan dan pendataan dapat ditarik kesimpulan: (1) Penanggulangan sampah melalui sosialisasi zero waste secara intensif dan monitoring di kawasan wisata Savana Propok berhasil membina wisatawan untuk tetap menjaga kebersihan dan kelestarian alam dengan tidak membuang sampah sembarangan dan kesadaran untuk kembali membawa sampah turun gunung; (2) Sosialisasi melalui pendekatan zero waste berhasil mempengaruhi pola pikir wisatawan terhadap sampah dengan merubah gaya hidup konsumtif dengan menolak penggunaan logistik sekali pakai yang berpotensi menjadi sampah.

Kata Kunci: Zero waste; sosialisasi; sampah; savana propok. 


\section{Pendahuluan}

Pariwisata merupakan salah satu industri yang paling banyak berpotensi untuk dikembagkan mengingat semakin meningkatnya permintaan produk wisata dari tahun ke tahun (Dinas Pariwisata Daerah Istimewa Yogyakarta, 2015). Gubernur Bank Indonesia Perry Warjiyo menyatakan bahwa optimalisasi pariwisata bisa menjadi sektor penyumbang devisa terbesar setelah kelapa sawit. Pasalnya, cakupan sektor pariwisata cukup luas, sehingga mampu menyerap banyak tenaga kerja. Menurut Kristianto (2015) sektor pariwisata tidak hanya berkontribusi terhadap pertumbuhan ekonomi lebih tinggi, tetapi juga menyerap banyak tenaga kerja, dan meningkatkan pendapatan ekonomi masyarakat. Oleh karena itu secara nasional, sektor pariwisata menjadi salah satu program prioritas dalam posisinya sebagai penghasil devisa terbesar.

Sebagai salah satus sektor ekonomi dengan pertumbuhan tercepat di dunia, trend peningkatan pariwisata di NTB selama satu dekade terakhir cukup signifikan dalam meningkatkan pertumbuhan ekonomi masyarakat (Taufan dalam Kicknews.today, 2019). Pertumbuhan ekonomi NTB Tahun 2017 mencapai 7,1 persen melampaui pertumbuhan ekonomi nasional (5,6 persen). Hal ini berkat dukungan sektor pertanian, pertambangan dan pariwisata (Fauzia, 2018). Karena konstribusi yang signifikan, sektor pariwisata tetap menjadi program unggulan dan menjanjikan di NTB.

Sebagai salah satu destinasi wisata utama di Indonesia, Provinsi NTB memiliki banyak tempat wisata yang mampu menarik datangnya wisatawan, baik domestik maupun mancanegara (Taufan, 2019). Oliver Oehms mengatakan, GIZ sebagai lembaga donor Jerman melihat potensi pariwisata di Pulau Lombok sangat luar biasa, bahkan akan menjadi ikon wisata dunia jika dikelola dengan baik. Salah satu wisata prioitas yang bekembang dengan baik di Pulau Lombok adalah pendakian gunung dengan tujuan untuk berpetualang, camping, menikmati panorama alam, interpetasi flora fauna, dan lain-lain.

Kabupaten Lombok Timur merupakan salah satu kabupaten di Pulau Lombok yang memiliki kawasan wisata yang potensial untuk pendakian gunung. Salah satu lokasi wisata tersebut adalah Savana Propok di kawasan Gunung Rinjani. Jalur pendakian menuju Propok mudah dilalui, dibutuhkan waktu kurang lebih 3 jam untuk mencapai tujuan. Keberadaan objek wisata ini tidak jauh dari jalan utama (jalan protokol), sehingga mudah diakses wisatawan. Walapun Savana Propok belum lama sebagai tempat wisata pendakian yang dimulai sejak tahun 2018, namun dalam 2 tahun terakhir ini telah mengundang banyak wisatawan, sehingga menjadi salah satu prioritas utama pengembangan wisata di Lombok Timur.

Makin populernya kegiatan mendaki gunung menuju Savana Propok membuat gunung di kawasan ini semakin ramai wisatawan. Bahkan pada momen tertentu kawasan ini sudah seperti pasar di musim liburan. Antusias kehadiran wisatawan khususnya untuk tahun baru (tahun akbar) 2020 di Savana Popok meningkat dibanding tahun lalu (Kelompok Sadar Wisata/Popdarwis, kom. pribadi). Hal ini menjadi tantangan petugas dalam penanganan masalah sampah. Hasil pantauan lapangan menunjukkan bahwa komitmen para wisatawan terkait penanganan sampah masih rendah. Walaupun pihak pengelola telah menyampaikan himbawan kepada para pendaki agar mereka tidak membuang sampah dan membawa turun kembali sampah bawaannya, namun masih banyak ditemukan sampah berserakan di areal padang savana dan pada jalur pendakian di hutan tropis. Kondisi ini cukup memprihatinkan dan menimbulkan kekawatiran yang mendalam terhadap kerusakan dan pencemaran lingkungan (kualitas tanah, air dan udara) yang pada akhirnya bisa membuat savana dan hutan tropis pegunungan kehilangan pesonannya. Untuk menyelamatan ekosistem dan meningkatkan kenyamanan wisatawan, 
maka penanggulangan masalah sampah perlu penanganan yang lebih intensif.

Salah satu pendekatan yang dapat dilakukan agar Savana Propok bebas sampah adalah dengan menerapkan konsep zero waste. Prinsip zero waste (nol sampah, bebas sampah) adalah berupaya semaksimal mungkin untuk meminimalisir produksi sampah hingga sama sekali tidak memproduksi sampah, tidak ada sampah dikirim ke TPA (daur ulang). Bea Johnson mempopulerkan prinsip $5 \mathrm{R}$, yaitu Refuse (menolak), Reduce (mengurangi), Reuse (menggunakan kembali), Recycle (daur ulang), dan Rot (membusukkan). Menurut Nirmala (2017), pendakian dengan prinsip zero waste bisa dilakukan dengan tidak membawa perbekalan yang menjadi sampah sejak awal. Mendaki gunung dengan membawa logistik yang tidak sekali pakai, misalnya botol minum sendiri (tumbled), kain lap pennganti tissue, dan tidak membawa bahan instant. Pada prinsipnya menolak bahan-bahan yang berpotensi sampah (tidak ramah lingkungan, sulit terurai, dan menjauhi single use plastic atau plastik yang tentu saja hanya sekali pakai).

Pendekatan zero waste dapat dipadukan dengan aturan yang telah berjalan yang mewajibkan wisatawan tidak membuang sampah sembarangan dan membawa sampah bawaannya turun dari gunung. Dalam rangka menunjang program zero waste yang digalakkan pemerintah Provinsi NTB, maka program tersebut perlu disosialisasikan untuk solusi penanganan dan antisipasi sampah pada kawasan wisata Savana Propok.

\section{Metode Pelaksanaan}

\section{Waktu dan Tempat Pelaksanaan}

Pengabdian ini dilaksanakan dalam dua tahap kegiatan, yaitu sosialisasi dan monitoring hasil sosialisasi. Sosialisasi zero waste dilaksanakan selama dua hari, yaitu 31 Desember 2019 sampai dengan 1 Januari 2020 pada dua lokasi yang berbeda. Sosialisasi hari pertama berlangsung di gerbang registrasi dan sosialisasi hari kedua pada kawasan pegunungan di Savana Propok. Monitoring kesadaran wisatawan yang membawa turun sampah dilakukan selama 3 hari di gebang registrasi, yaitu pada 2 Februari 2020 sampai dengan 4 Februari 2020. Monitoring hasil sosialisasi zero waste bagi para wisatawan akan mendaki lagi dilaksanakan di gerbang registrasi. Kegiatan ini berlangsung selama sepuluh hari, yaitu pada 11 Januari 2020 sampai dengan 20 Januari 2020.

\section{Alat dan Bahan}

Alat yang diperlukan untuk kegiatan sosialisasi adalah kamera foto, kamera video, dan perekam suara. Bahan yang diperlukan yaitu kantung plastik (trash bag), spidol, dan buku registrasi.

\section{Pelaksanaan Sosialisasi dan Monitoring}

Sosialisasi zero waste dan himbawan
membawa turun sampah di gerbang
registrasi

Sosialisasi zero waste pada gerbang registrasi pada 31 Desember 2019 dilaksanakan terhadap setiap pendaki atau kelompok pendaki yang akan menuju camping ground di Savana Propok. Materi sosialisasi berupa arahan atau ceramah tentang prinsip utama konsep zero waste. Zero waste dapat dilakukan dengan mengubah gaya hidup untuk tidak membawa bahan-bahan yang dapat menjadi sampah, terutama botol minuman dari bahan plastik sekali pakai dan bahan sekali pakai lainya yang tidak ramah lingkungan. Dalam sosialisasi ini para pendaki dihimbau agar menjaga kebersihan lingkungan di tempat wisata dengan membawa turun kembali sampah bawaannya ke base camp di pintu gerbang. Untuk membawa sampah pulang, setiap pendaki atau kelompok pendaki diberi kantung plastik (trash bag) yang telah diberi label untuk memudahkan dalam monitoring.

Sampel wisatawan yang digunakan dalam kegiatan ini terdata 20 kelompok. Bagi wisatawan atau pendaki yang membawa 
turun semua sampah bawaanya, maka saat sampai di base camp akan mendapat reward atau penghargaan dari Kelompok Sadar Wisata (Pokdarwis) yang mengelola area wisata di Propok.

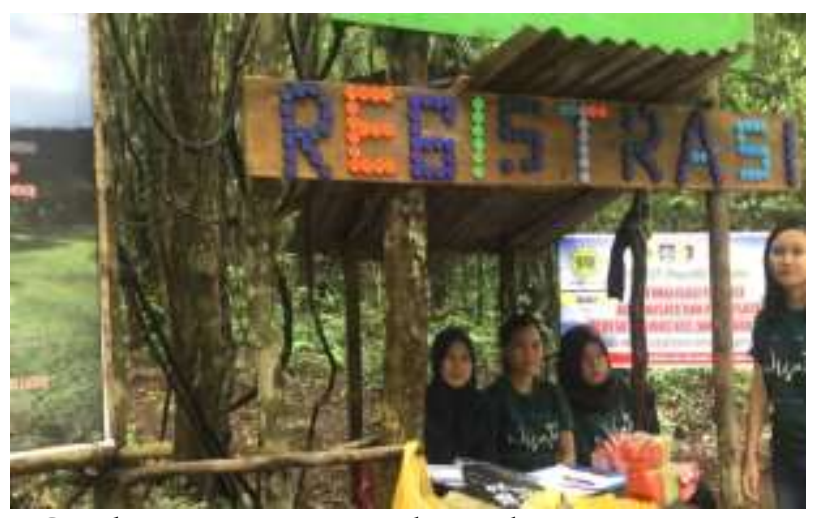

Gambar 1. Petugas sosialisasi di pintu registrasi.

\section{Sosialisasi zero waste di area wisata Savana Propok}

Sosialisasi zero waste pada 1 Januari 2020 dilakukan pada camping ground di Savana Propok bertepatan dengan camping akbar. Pada saat sosialisasi jumlah wisatawan sangat banyak, mereka datang untuk merayakan pergantian tahun di Savana Propok. Sampel kelompok wisatawan yang digunakan pada kegiatan ini sebanyak 15 kelompok. Materi sosialisasi yang disampaikan lebih menekankan pada peralatan dan bahan yang sebaiknya dibawa sebagai pendaki zero waste baik domestik maupun mancanegara. Petugas sosialisasi juga menunjukkan kepada para wisatawan contoh-contoh logistik yang tidak berpotensi menjadi sampah.

Proses sosialisasi dilakukan secara langsung oleh tim pengabdian dan petugas sosialisasi dari Kelompok Sadar Wisata (Pokdarwis) kepada para wisatawan menggunakan metode direct selling atau berkunjung dari tenda ke tenda atau dengan cara ikut bergabung face to face dalam kelompok-kelompok wisatawan. Setelah dilakukan sosialisasi, selanjutnya dilakukan pendataan identitas wisatawan atau kelompok wisatawan untuk memantau perubahan perilaku mereka pada kunjungan berikutnya setelah aplikasi konsep zero waste diterapkan.

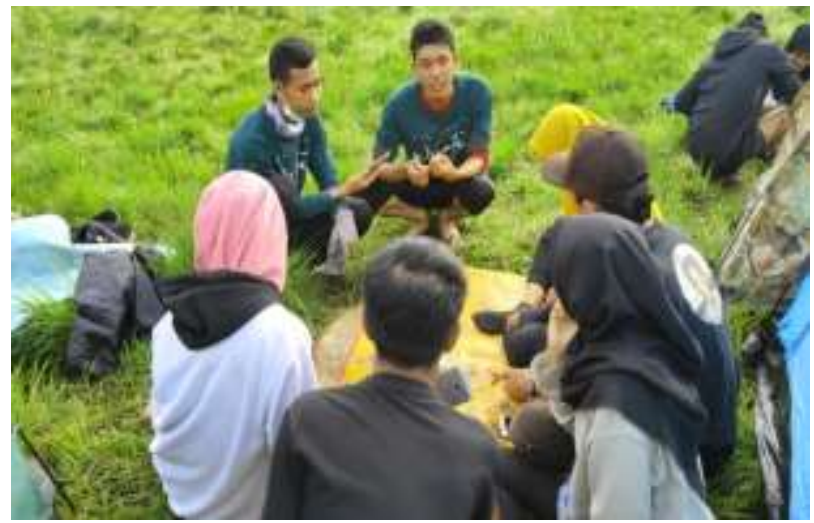

Gambar 2. Sosialisasi logistik zero waste di area camping ground Savana Propok.

Selain sosialisasi zero waste, pada area savana juga dilakukan monitoring terhadap para pendaki/wisatawan yang melakukan pengemasan sampah dalam trash bag (kantong plastik) untuk dibawa turun ke base camp.

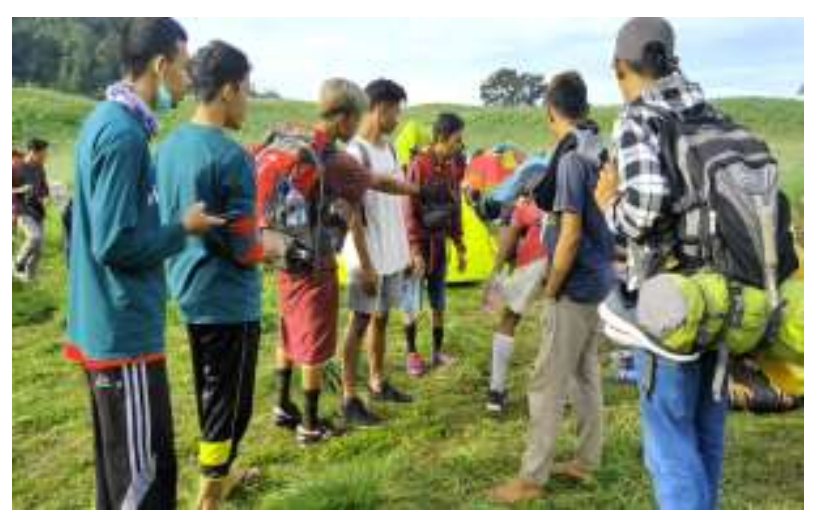

Gambar 3. Proses bersih sampah dan sosialisasi zero waste oleh fasilitator di Savana Propok.

\section{Monitoring wisatawan yang membawa turun sampah di gerbang registrasi}

Untuk mengetahui komitmen wisatawan yang membawa sampah turun, dilakukan pengawasan terhadap wisatawan yang pulang pada gerbang registrasi. Kegiatan pendataan dilaksanakan selama tiga hari dari pagi sampai sore. Petugas pada bagian registrasi mendata 20 sampel kelompok wisatawan yang membawa kantong plastik (trash bag) berisi sampah dan wisatawan yang tidak membawa sampah. 
Monitoring wisatawan yang melaksanakan zero waste dengan membawa barang tidak berpotensi sampah di gerbang registrasi

Untuk memastikan komitmen wisatawan yang melaksanakan program zero waste, maka selama sepuluh hari dilakukan pendataan terhadap 15 kelompok wisatawan yang akan mendaki lagi ke Savana Propok. Sampel merupakan para pendaki yang pernah mendapat sosiasisasi zero waste di Savana Propok. Pengambilan data dilakukan seminggu setelah sosialisasi karena berdasarkan data pada Pokdarwis, banyak wisatawan yang kembali lagi satu minggu setelah pendakian. Petugas pada gerbang registrasi bertugas memeriksa barang bawaan para pendaki/wisatawan sampel. Hal ini dilakukan untuk memastikan konsep zero waste dengan prinsip Refuse (menolak) barang bawaan berpotensi sampah yang telah disosialisasikan sudah dapat diterima dan dilaksanakan atau belum.

\section{Hasil dan Pembahasan}

Kegiatan sosialisasi zero waste yang dilakukan oleh tim pengabdian bersama Kelompok Sadar Wisata (Pokdarwis) bertujuan untuk memberikan pemahaman kepada wisatawan domestik dan mancanegara terhadap pentingnya melestarikan lingkungan di daerah wisata yang bebas dari sampah baik organik maupun non organik. Berdasarkan informasi yang di dapatkan dari Pokdarwis dan hasil pemantauan di lapangan, bahwa wisatawan kurang memiliki kesadaran akan kebersihan. Namun setelah diberikan sosialisasi, wisatawan dapat mengerti dan bersama-sama menjaga kebersihan kawasan Savana Propok.

Setelah dilakukan himbawan kepada masing-masing kelompok untuk membawa turun sampah dari area camping dengan wadah plastik trash bag yang diberikan petuga pada 20 sampel wisatawan diperoleh hasil seperti ditampilkan pada Gambar 4.

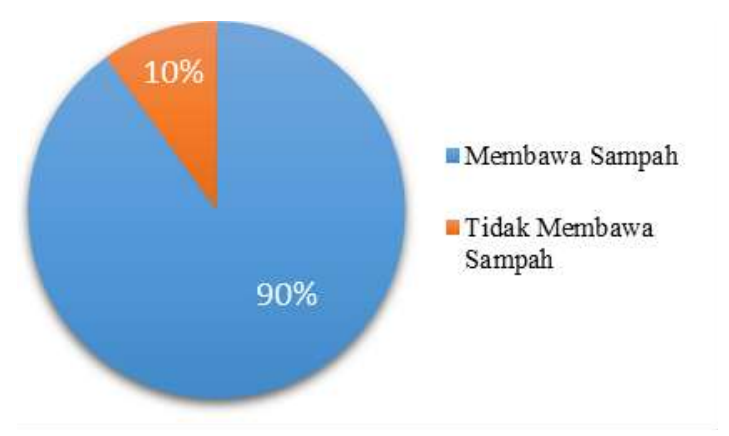

Gambar 4. Perbandingan wisatawan membawa turun sampah dan wisatawan tidak membawa turun sampah.

Gambar 4 menunjukkan bahwa kesadaran wisatawan untuk membawa turun sampah sudah baik. Hasil pantauan 20 kelompok wisatawan yang turun dari Savana Propok, 18 kelompok (90\%) wisatawan telah mematuhi himbauan atau arahan dari pengelola dan tim pengabdian dengan membawa turun sampah bawaannya. Hanya 2 kelompok (10\%) wisatawan yang belum ada kesadaran. Hal ini mengindikasikan bahwa mayoritas wisatawan pendaki sudah menyadari pentingnya menjaga kebersihan dengan membawa turun sampah dari tempat camping.

Sosialisasi zero waste yang dilakukan di area camping Savana Propok dilakukan terhadap 15 kelompok sampel wisatawan. Hasil pantauan lapangan menunjukkan bahwa dari 15 kelompok tersebut hanya 6 kelompok yang mendaki kembali ke Savana Propok dalam bulan Januari 2020. Dari hasil pendataan yang dilakukan, diperoleh informasi bahwa 4 kelompok (67\%) wisatawan telah menerapkan zero waste (Gambar 5), seperti telah mengganti botol air minum sekali pakai dengan botol kaca dan jeriken, membawa makanan dengan menggunakan kotak makanan, tidak lagi membawa minuman kaleng, dan tidak membawa sabun serta shampoo yang bepotensi mencemari lingkungan di sumber air Savana Propok. 


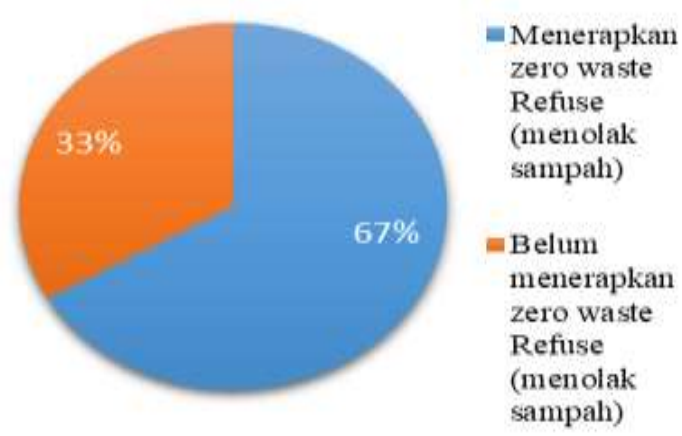

Gambar 5. Penerapan Zero Waste di Savana Propok

Hasi tersebut sebagaimana ditampilkan pada Gambar 5 menunjukkan bahwa sosialisasi zero waste yang dilakukan, cukup berhasil memberikan kesadaran kepada wisatawan pendaki gunung untuk tidak membawa makanan dan minuman yang berpotensi menjadi sampah.

\section{Kesimpulan}

Berdasarkan hasil sosialisasi dan monitoring aplikasi konsep zero waste dapat ditarik kesimpulan: 1) Penanggulangan sampah melalui sosialisasi zero waste secara intensif dan monitoring di kawasan wisata Savana Propok berhasil membina wisatawan untuk tetap menjaga kebersihan dan kelestarian alam dengan tidak membuang sampah sembarangan dan kesadaran untuk kembali membawa sampah turun gunung. 2) Sosialisasi melalui pendekatan zero waste berhasil mempengaruhi pola pikir wisatawan dengan merubah gaya hidup konsumtif dengan menolak penggunaan logistik sekali pakai yang berpotensi menjadi sampah.

\section{Daftar Pustaka}

Fauzia, M. (2018). Pertumbuhan Ekonomi NTB 7,1 Persen, Melebihi Pertumbuhan Ekonomi Nasional. Kompas.com. Jakarta.
Taufan. (2019). Arah Pembangunan Pariwisata Berkelanjutan di NTB Tahun 2019. kicknews.today. Mataram.

Kristianto, B. (2015). Penguatan Sumber Daya Manusia Pariwisata Dalam Masyarakat Ekonomi ASEAN (MEA), dalam Persiapan Sektor Pariwisata Indonesia dalam Menghadapi Masyarakat Ekonomi ASEAN 2015. Editor oleh: Agus Syarif Hidayat. Lembaga Ilmu Pengetahuan Indonesia (LIPI) Pusat Penelitian Ekonomi. LIPI Press. Jakarta.

Nirmala, S. (2017). Zero Waste Adventure. Ekspedisi Nol Sampah.

Dinas Pariwisata Daerah Istimewa Yogyakarta. (2015). Statistik Kepariwistataan 2015 jogja istimewa. www.visitingjogja.com. Yogyakarta. 